\title{
Caregivers' Education in Global Time: The Case of Filipina Domestic Workers in Singapore
}

\author{
Daphna Arbell Kehila \\ Independent Researcher
}

This paper links the results of an explorative case study with quantitative data from a survey in order to present the complex personal, societal, economic and cultural factors that influence foreign domestic workers' (FDWs) experiences as home-based caregivers. A lack of coordinated, systematic training programs for live-in FDWs hinders their social mobility as well as quality of home-care practices. The author suggests a paradigm shift towards creating collaborative relationships between professionals in healthcare and education, with home-caregivers, in order to create new model of bi-directional education. The researcher calls for an examination of lay-knowledge of caregivers in order to advance training programs, and in hope to shape new, multifaceted, and inclusive pedagogy required for the future of adult education in a globalised world. The author argues that FDWs' experiential learning and lay knowledge should be recognized as valuable, relevant, and integral for future research, regardless of their access to conventional modes of accreditation and education.

Keywords: caregivers, migrants, domestic workers, Singapore, lay-knowledge

\section{INTRODUCTION}

Economic development, imperatives, and incentives for women to find employment abroad affects the migration of domestic workers and home-based carers around East and South-East Asia (Taya, 2016). Low fertility rates, an aging demographic, an increase in female employment, combined with long-term healthcare provisions, create changes in lifestyle and a growing demand for home-based caregiving. This trend is expected to increase worldwide and will therefore require on-going training and support for home-based caregivers.

This paper focuses on a qualitative case study conducted in Singapore during 2017 to 2018, with five Filipina domestic workers who volunteer as caregiving instructors for their peers in a non-formal education program that the workers autonomously initiated, developed, and implemented. The results of an additional quantitative survey conducted by the author in 2019, of 140 workers from the same program, created a new vision for the education of foreign domestic workers (FDWs) who work as caregivers. This paper commences with a description of the context of the studies and related literature review, followed by the methodology and results, conclusions and recommendations.

\section{The Context: Training Programs for Caregivers at HOME Academy}

The Humanitarian Organisation for Migration Economics (HOME) is a not-for-profit, charity-based, non-governmental organization (NGO) that is primarily engaged in the direct service provision of health, 
education, legal support, and the social advocacy for migrant workers in Singapore (http://myvoiceathome.org/tag/home-academy/). The qualitative case study is thereby situated in the context of a unique non-formal education program offered to FDWs to support their skills and adjustment to their work demands in Singapore. As a grassroots support organization (GSO) providing training and education services for FDWs, by FDWs, the HOME Academy provides classes such as but not limited to English, computer proficiency, sewing, cooking; built according to and for the interests of FDWs who build, and teach, the courses themselves.

The development of the care-givers' training program (CTP) at HOME Academy has been in operation since 2009 and has evolved based on the needs expressed by the FDWs. The Caregiving program is bilevelled - basic and advanced care - focusing primarily on elder-care. A nursing-aide course and child-care course are offered to students who prefer to focus in these areas. Despite being the most demanding course in terms of time and monetary investment, the CTP's popularity is credited to the acknowledgement that caregiver education provides meaningful opportunities for social mobility (Kehila, 2018).

The CTP includes both hands-on and theoretical study, focusing primarily on emergency and safety procedures, medical conditions, vital-signs, medication management, and soft skills (e.g., holistic care, emotional support, and communication skills with care recipients). Students are provided with books in English, which include information that the volunteer teachers compile from various sources, and which aim to follow the standard of caregiver competency as set by the Singapore government.

HOME Academy offers an advantage in that it provides students opportunities to engage in long-term learning, supported by their peers and teachers from the FDW community. The author's role as a volunteer teacher afforded her membership in the community of FDWs, where she conducted her case study focused on caregiver knowledge development, followed by a survey of students, and the on-going development of the CTP.

\section{LITERATURE REVIEW}

The complex interdisciplinary areas related to transnational migration, domestic work and home-based caregiving, and policies/cultural influences in both sending and hosting countries (Choi \& Lyons, 2012; Constable, 2014; Lam, Yeoh \& Huang, 2006) have received more attention by scholars and organizations, such as the International Labor Organization (ILO) and the World Health Organization (WHO) due to the growing needs for home-based caregiving. The ILO report (Tayah, 2016) highlighted the economic contribution of more than eleven-million migrant domestic workers globally. The care chain (Hochschild, 2000) has evolved from informal, unpaid care to paid home-based care-work (Beneria, 2008; Benhabib \& Resnik, 2009; Isaksen, Devi, \& Hochschild, 2008; Piper, 2008; Tronto, 2002; 2007; 2013; Yeates, 2011; 2012).

Despite the relevance of domestic work, and the importance of home-based care-giving, both nationally and internationally, there is almost no research literature on the experiences and education of women who migrate for domestic work. Most of the literature related to domestic workers focuses on the work conditions, human rights, and legal issues (Blackett, 2012; Choudry \& Smith, 2016; Devasahayam \& Yeoh, 2007; Elias, 2010; Huang, Yeoh, \& Toyota, 2012; Islam \& Cojocaru, 2016; Sollund \& Leonard, 2012; Suleman, 2015). The social relations of care-work, associated with the household to the function of the labor market in Southeast Asia, provide insights about the development of significant networks of activists, advocacy groups, and NGOs in the region (Carney, 2010; Elias, 2010; Huang, Yeoh, \& Toyota, 2012).

\section{Singapore Policies on Domestic Workers and Family Caregiving}

Given that care-work in cultures of East Asia is confined to the private sphere (Carney, 2010; Cortes \& Pan, 2009; Okamoto, Momose, Fujino \& Osawa, 2009; Mackenzie \& Holroyd, 1996; Ueno, 2008), FDWs are a low-cost solution for Singapore's care deficit, which remains within the private realm. More than sixty percent of families in Singapore employ FDWs as primary caretakers of the household, children, and the elderly (Basnyat \& Chang, 2017; Østbye, Malhotra, Malhotra, Arambepola \& Chan, 2013; Heng, Fan \& Chan, 2019). Currently, FDWs are the long-term care implementers for the majority of patients with 
disabilities in Singapore, without recognition or sufficient care-training (How \& Fock, 2014; Kehila, 2018; Østbye, Malhotra, Malhotra, Arambepola, \& Chan, 2013; Tang, Chong, Goh, Chan, \& Choo, 2012). The relationship between FDWs and family caregivers is characterized by mutual dependency (Basnyat and Chang, 2017; Kehila, 2018; Walsh \& Shutes, 2013), as care dynamics are negotiated between practices of control, surveillance, and recognition (Tan, 2019).

Since 1978, Singapore has allowed controlled recruitment of FDWs from neighbouring Asian countries, such as the Philippines, India, Myanmar, Indonesia, and Sri Lanka (Yeoh, Huang, \& Gonzales, 1999), resulting in a staggering 255,800 female domestic workers in Singapore on Work Permits as of December 2019 ((MOM, 2019), serving a total of 1.372,400 million households (https://www.singstat.gov.sg/finddata/search-by-theme/households/households/latest-data). The exclusion of these workers from The Employment Act means that they are not protected and can face various kinds of abuse, lack of care by employers and recruitment agencies, and even expulsion from the country (Heng, Fan \& Chan, 2019; Huang \& Yeoh, 2007; Lyer, Devasahayam, \& Yeoh, 2004; Wessels, 2015; Yeoh \& Huang, 2009). Due to these legislative gaps, and despite the significant role of FDWs, their rights and access to resources such as education and training is compromised (Kehila, 2018). These gaps also encourage a free market of training programs to proliferate with no clear standards and guidelines for quality of care and training.

\section{Care Knowledge and Practice}

The complex field of care knowledge and practice requires on-going exploration and development (Salvador-Carulla, 2010; Watson \& Smith, 2001) to follow advancements in healthcare technology. Morse et al. (1990) identified professional caring as a paradigm unique to nursing, whilst the knowledge of nonformal home-caregivers is considered lay-knowledge (Given, Sherwood \& Given, 2008; Kitson, 2003; Lewin, Dick, Pond, Zwarenstein, Aja, vanWyk, \& Patrick, 2005). The literature focused on care-work emphasizes care skills and tasks, suggesting a range of proficiencies and cultural influences (Hampson \& Junor,2009; Imamura, Saito \& Miyagi, 2010; Given, Sherwood \& Given, 2008). Therefore, recognition of the prominence of care-work to the well-being of the society as a whole, in both sending and hosting countries, is critical to the development of education programs and support for FDWs who work as caregivers.

\section{METHODOLOGY}

A qualitative exploratory case study was conducted to explore the development of live-in FDW caregivers' lay knowledge. Five Filipina FDWs who volunteer as caregiving teachers for fellow FDWs at HOME Academy agreed to participate. This case study drew upon methodological approaches for qualitative interviewing and researcher-participant observation (Charmaz, 2001). Data were collected over six months, including two semi-structured personal interviews, and one focus group, conducted in a natural setting where people were engaged in the process under study. Data were analyzed using a three-step ethnographic process of direct observation combined with interview; emphasizing local knowledge, context, and direct personal engagement of the researcher with the FDW community. Observations, artefacts, and personal memos were collected to support the validation of data from the interviews and to deepen analysis.

\section{RESULTS}

\section{Influences on Caregivers' Lay Knowledge Development}

In their narratives, the FDWs described the process and influences on their lay knowledge development through various life experiences; prior and along their migration process; as consequences of their relationships as caregivers, and as HOME Academy teachers. They highlighted migration as a trigger for learning, as well as developmental and behavioral changes which challenged and stimulated selfdevelopment. Hence, care knowledge is not limited to the practice of on-the-job skills, but deeply relates to social status, economic mobility, identity development and life experiences that have purpose and meaning. 
The caregivers articulated their commitment and passion for care practices as a profession bestowing life-meaning. However, they did not explicitly prioritize their passion or commitment for creating knowledge; but rather for transferring and sharing experiences and knowledge as a way to empower other FDWs and further their caregiving skills. The results indicated that their paramount passion and commitment was for: (a) caregiving as life meaning and (b) for creating opportunities for social mobility. These aspects of care-work are specifically shared between FDWs, teachers and students, during their faceto face interaction rather than through online learning networks. Hence, although the FDWs may find information and support online, their professional identity as caregivers is deeply tied to, and developed through, face-to face mentorship in a community of learners.

The study highlighted gaps and fragmentation in the Filipina FDWs' knowledge and care practice's implementation. Although the caregivers developed perspective on their own experiences of caregiving, they encountered difficulty recognizing their knowledge until it was institutionally articulated as formal knowledge. In other words, despite their deep understanding of the reality and challenges involved in homebased care-work in a multicultural work environment, the volunteer teachers develop their notions of care knowledge based on acceptance of existing mainstream training programs for caregivers, which is characteristic of the formal and commodified system of care training they encounter in Singapore, their home country (Philippines), and online.

\section{FDWS as Learners}

In order to learn about the FDWs' needs and expectations regarding the training program, a questionnaire was administered by the author in September 2019 that related to three areas: a) demographic and caregiving education background; b) care, tasks, and responsibilities; c) care-work supervision, mentorship, and self-learning practices. Data were collected from 140 students from four CTP classes. The results indicated that the students are FDWs from four countries of origin: India, Indonesia, Myanmar, and the Philippines, between ages twenty to fifty-five. Despite the Singapore government's focus on eldercare, there are more participants caring for children, in some cases who also care for elderly members of the same household. Seven participants reported working with persons with disabilities (PWD). Notably, although some elderly persons have disabilities, the FDWs do not consider them as PWD unless they are identified medically.

The data confirmed that the majority of FDWs come to Singapore with no previous training for carework. Lack of prior training reflects the lack of related policies, and the approach to home-based care-work as unskilled work. This approach ignores the challenges faced by FDWs, not only in terms of their work expectations; but who migrate from foreign countries, and who often face communication challenges with their employer and care-recipient. The results highlight areas of daily care-work routines the FDWs are expected to carry out despite the lack of training. In addition to care-work the FDW have other responsibilities in maintaining the household, which may also require specific training and skills, such as safety measures, operating equipment, cooking, organisation of daily routines, and reporting practices.

The data revealed that the majority of FDWs are proactive in searching for information and developing their knowledge by using various online tools (such as Google search, YouTube, and Wikipedia), and networking through social media (such as Facebook and Twitter) in search of information and guidance related to the challenges they face as migrants in foreign country and as caregivers. The FDWs reflected on their use of online resources, indicating that they are the main communication channels available to them. However, the use of these resources is subject to employer restrictions. The survey results indicated that about 77 percent of the FDWs would like to have access to learning opportunities via their mobile devices. The areas of training that they are most keen about are using home medical-equipment, understanding medical conditions, and identifying vital-signs, learning about diet-management and food preparation, dealing with emotional stress, understanding their client, emergency practices, and monitoring medication intake.

The students are highly motivated, strongly connected and supportive of each other, and these links are strongly based on nationality. Despite linguistic challenges, 81 percent of the FDWs are positive about online training in English. The community contributes to their confidence, empowers participants, moves 
them to invest some of their small income in these education programs, and motivates their commitment to learning and self-development. The students view HOME Academy as an opportunity for professional mobility, training and accreditation that may assist them in obtaining better job conditions, status, and recognition.

\section{Adult Education for Migrant Care-Workers}

Guo and Lange (2015) argue that adult educators need to understand the complexities of migration and immigration and reconstitute educational practices that can expand the application of social justice, human rights, social inclusion, community resilience, and reciprocal integration. Recognition of the knowledge gained through caregiving experiences, and the contribution of the FDWs to the economies of the sending and hosting countries, and to the well-being of the employers' families, are important to forging identities that rely on social mobility and inclusion. The FDWs who become the breadwinners for their families leave their home-countries and travel to a foreign place, have to learn new languages, adapt to new cultures, and observe and connect with other people in the most intimate ways, while living in their employers' homes and caring for their families.

It is notable that the majority of FDWs lack access to formal education. Live-in FDWs in Singapore often experience isolation, restriction, and control at their employer's home. In many cases FDWs are not given a day-off work; the FDWs are expected to be available 24/7 for the needs of their employers and care-recipients. The case study raised the voices, experiences, and perspectives of FDWs, who are members of various socially marginalized groups: women, migrants, domestic workers, care-workers, and families who are supported by FDWs' relatives. Another layer of marginalization voiced by this study concerns the epistemic warrant of lay knowledge as it is compared with professional institutionalised, and socially recognised knowledge. Although Kolb's (1984) theory of experiential learning, along with other scholars, acknowledged experience as a source of informal learning and at the very center of knowledge production and acquisition, socially recognised 'knowledge' is often predicated upon formal and institutionalised training. Thus, denying FDWs from formal education may hinder them not only from being recognized as learners by society, but from recognizing themselves as learners in social and work contexts. For this reason, this study recognised FDWs' knowledge and their right to know, highlighting their role in the learning community as fundamental to transforming their social class and individual identities.

Access to education and training is essential to increase caregiver's effectiveness and their feelings of competence as well as reduce caregivers' subjective and objective burdens (Belgacem, Auclair, Fedor, Brugnon, Blanquet, Tournilhac, \& Gerbaud, 2013; Chen, Hedrick \& Young, 2010; Etemadifar, Bahrami, Shahriari, \& Farsani, 2014). The gap between available education for caregivers and the needs of FDWs reveals the necessity for new methodologies and approaches. While this research presented a model of faceto-face mentoring for FDWs by FDWs in the learning community of HOME Academy, the challenges faced by millions of FDWs around the world suggest that blended education, including online tools, mentorship, and social platforms are essential avenues to explore and develop (Argente-Linares, Pérez-López \& Ordóñez-Solana, 2016). The use of mobile-apps can provide resources for problem-solving and stress reduction strategies for caregivers. (Grossman, Zak, \& Zelinski, 2018). These platforms and technologies may increase access to relevant information from care professionals, and social support from other caregivers. Through these tools and strategies, the FDW can share knowledge and experiences with her community, develop her hybrid identities; as a woman, as a learner and as a care-worker. Their initiative to create a non-formal education program is evident by their motivation and commitment not only to upgrade their knowledge and skills in order to care better for their employers, but also to transform the transnational care structures in changing social, political and economic systems.

\section{CONCLUSION}

Education of home-based caregivers globally requires FDWs to develop complex skills, professionally and culturally, in order to be able to communicate and to collaborate in the blurred borders of roles when juxtaposed with the intimacy, trust and care involved in their job. It is paramount that adult education 
programs for FDWs consider language and cultural differences, multiple ways of knowing, platforms and technology tools, law, policies, and knowledge systems in both home country and host country of the caregiver.

Learning about the knowledge of FDWs revealed new perspectives on home-caregiving practices and the development of caregivers on-the-job and by participation in a transnational migration learning community. Recognition of caregivers' lay-knowledge, their role in advancing training programs for homebased caregivers and shaping new multifaceted and inclusive pedagogy, is required for the future advancement of adult education in a global world. Collaborative innovations between professionals from the host country community and the FDWs community may catalyze the bridging of lay and professional knowledge. It is important to conduct further research to collect evidence regarding communication between employers, workers, and care professionals that explores new avenues for collaboration, develop new knowledge and technologies, and apply home-care systems where FDWs play more significant roles.

\section{REFERENCES}

Argente-Linares, E., Pérez-López, M.C., \& Ordóñez-Solana, C. (2016). Practical experience of blended mentoring in higher education. Mentoring \& Tutoring: Partnership in Learning, 24(5), 399-414.

Bakhtiari, S., \& Shajar, H. (2006). Globalization and education: Challenges and opportunities. International Business \& Economics Research Journal (IBER), 5(2). https://doi.org/10.19030/iber.v5i2.3461

Basnyat, I., \& Chang, L. (2017). Examining live-in foreign domestic helpers as a coping resource for family caregivers of people with dementia in Singapore. Health Communication, 32(9), 11711179.

Belgacem, B., Auclair, C., Fedor, M.C., Brugnon, D., Blanquet, M., Tournilhac, O., \& Gerbaud, L. (2013). A caregiver educational program improves quality of life and burden for cancer patients and their caregivers: A randomised clinical trial. European Journal of Oncology Nursing, 17(6), $870-876$.

Benería, L. (2008). The crisis of care, international migration, and public policy. Feminist Economics, 14(3), 1-21. https://doi.org/10.1080/13545700802081984

Benhabib, S., \& Resnik, J. (Eds.). (2009). Migrations and mobilities: Citizenship, borders, and gender. New York, NY: NYU Press.

Blackett, A. (2012). The decent work for domestic workers convention and recommendation, 2011. American Journal of International Law, 106(4), 778-794.

Carney, T. (2010). A regional disability tribunal for Asia and the Pacific: Helping to change the conversation? The University of Sydney, Legal Studies Research Paper No. 10/92. Retrieved from http://papers.ssrn.com/sol3/papers.cfm?abstract_id=1688146

Charmaz, K., \& Mitchell, R.G. (2001). Grounded theory in ethnography. In P. Atkinson (Ed.), Handbook of ethnography (pp. 160-174). London, UK: SAGE.

Chen, Y.M., Hedrick, S.C., \& Young, H.M. (2010). A pilot evaluation of the family caregiver support program. Evaluation and Program Planning, 33(2), 113-119.

Choi, S., \& Lyons, L. (2012). Gender, citizenship, and women's 'unskilled' labour: The experience of Filipino migrant nurses in Singapore. Canadian Journal of Women and the Law/Revue Femmes et Droit, 24(1), 1-26. https://doi.org/10.3138/cjwl.24.1.001

Choudry, A., \& Smith, A. (Eds.). (2016). Unfree labour?: Struggles of migrant and immigrant workers in Canada. Oakland, CA: PM Press.

Constable, N. (2014). Born out of place: Migrant mothers and the politics of international labor. Hong Kong, CN: Hong Kong University Press.

Cortes, P., \& Pan, J. (2009). Outsourcing household production: The demand for foreign domestic helpers and native labor supply in Hong Kong. Chicago, IL: Booth School of Business, University of Chicago. 
Devasahayam, T.W., \& Yeoh, B.S. (Eds.). (2007). Working and mothering in Asia: Images, ideologies and identities (Vol. 1). Singapore: National University of Singapore Press.

Elias, J. (2010). Gendered political economy and the politics of migrant worker rights: The view from South-East Asia. Australian Journal of International Affairs, 64(1), 70-85. https://doi.org/10.1080/10357710903460022

Etemadifar, S., Bahrami, M., Shahriari, M., \& Farsani, A.K. (2014). The effectiveness of a supportive educative group intervention on family caregiver burden of patients with heart failure. Iranian Journal of Nursing and Midwifery Research, 19(3), 217.

Given, B., Sherwood, P.R., \& Given, C.W. (2008). What knowledge and skills do caregivers need? Journal of Social Work Education, 44(3), 115-123. https://doi.org/10.5175/JSWE.2008.773247703

Grossman, M.R., Zak, D.K., \& Zelinski, E.M. (2018). Mobile Apps for caregivers of older adults: Quantitative content analysis. JMIR mHealth and uHealth, 6(7), e162.

Guo, S. (2015). The changing nature of adult education in the age of transnational migration: Toward a model of recognitive adult education. In S. Guo \& E. Lange (Eds.), New Directions for Adult and Continuing Education, 146, 7-17. Sun Francisco, CA: Jossey Bass. doi: 10.1002/ace.20127

Hampson, I., \& Junor, A. (2009). Employability and the substance of soft skills. In Proceedings of the 27th International Labour Process Conference.

Heng, J.L., Fan, E., \& Chan, E.Y. (2019). Caregiving experiences, coping strategies and needs of foreign domestic workers caring for older people. Journal of Clinical Nursing, 28(3-4), 458-468.

Hochschild, A.R. (2000). Global care chains and emotional surplus value. On the Edge: Living With Global Capitalism, 3(5), 130-46.

How, C.H., \& Fock, K.M. (2014). Healthcare in Singapore: The present and future. Singapore Medical Journal, 55(3), 126. doi: 10.11622/smedj.2014027

Huang, S., \& Yeoh, B.S.A. (2007). Emotional labour and transnational domestic work: The moving geographies of 'Maid Abuse' in Singapore. Mobilities, 2(2), 195-217. https://doi.org/10.1080/17450100701381557

Huang, S., Yeoh, B.S., \& Toyota, M. (2012). Caring for the elderly: The embodied labour of migrant care-workers in Singapore. Global Networks, 12(2), 195-215. https://doi.org/10.1111/j.14710374.2012.00347.x

ILO. (2011). Convention No. 189 Decent work for domestic workers. Retrieved from http://www.ilo.org/wcmsp5/groups/public/@ed_protect/@protrav/@travail/documents/publicatio n/wcms_161104.pdf

ILO. (2015). Migrant domestic workers across the world: Global and regional estimates. Retrieved from http://www.ilo.org/wcmsp5/groups/public/---dgreports/--dcomm/documents/publication/wcms_436343.pdf

Imamura, T., Saito, I., \& Miyagi, M. (2010). The characteristics and skills of Filipino caregivers: FOW as human resources for work life balance in Japan (2). 立正大学心理学研究所紀要, 8, 17-27. Retrieved from http://hdl.handle.net/11266/5194

Isaksen, L.W., Devi, S.U., \& Hochschild, A.R. (2008). Global care crisis: A problem of capital, care chain, or commons? American Behavioral Scientist, 52(3), 405-425. https://doi.org/10.1177/0002764208323513

Islam, M.R., \& Cojocaru, S. (2016). Migrant domestic workers in Asia: Transnational variations and policy concerns. International Migration, 54(1), 48-63.

Kehila, D.A. (2018). Developing and managing knowledge and practice of care-giving: The case of Filipina domestic workers in Singapore (Doctoral dissertation, Lesley University). doi: 10.13140/RG.2.2.15889.48481

Kitson, A.L. (2003). A comparative analysis of lay-caring and professional (nursing) caring relationships. International Journal of Nursing Studies, 40(5), 503-510. https://doi.org/10.1016/S00207489(03)00065-8 
Lam, T., Yeoh, B.S., \& Huang, S. (2006). Global householding in a city-state: Emerging trends in Singapore. International Development Planning Review, 28(4), 475-497. https://doi.org/10.3828/idpr.28.4.3

Lewin, S.A., Dick, J., Pond, P., Zwarenstein, M., Aja, G., van Wyk, B., . . Patrick, M. (2005). Lay health workers in primary and community health care. International Journal of Epidemiology, 34(6), $1250-1251$.

Lyer, A., Devasahayam, T.W., \& Yeoh, B.S. (2004). A clean bill of health: Filipinas as domestic workers in Singapore. Asian and Pacific Migration Research Network, 13, 11-38. https://doi.org/10.1177/011719680401300102

Mackenzie, A.E., \& Holroyd, E.E. (1996). An exploration of the carers' perceptions of caregiving and caring responsibilities in Chinese families. International Journal of Nursing Studies, 33(1), 1-12.

MOM: Foreign workforce numbers. (n.d.). Retrieved February 2020, from http://www.mom.gov.sg/documents-and-publications/foreign-workforce-numbers

MOM: Foreign domestic worker eligibility. (n.d.). Retrieved February 2020, from https://www.mom.gov.sg/passes-and-permits/work-permit-for-foreign-domesticworker/eligibility-and-requirements/fdw-eligibility

MOM: Educational requirements for first-time foreign domestic workers. (n.d.). Retrieved February 2020, from https://www.mom.gov.sg/ /media/mom/documents/publications/educationalqualifications/educational-requirements-for-first-time-fdws.pdf?la=en

Morse, J.M., Solberg, S.M., Neander, W.L., Bottorff, J.L., \& Johnson, J.L. (1990). Concepts of caring and caring as a concept. ANS. Advances in Nursing Science, 13(1), 1-14.

Okamoto, K., Momose, Y., Fujino, A., \& Osawa, Y. (2009). Life worth living for caregiving and caregiver burden among Japanese caregivers of the disabled elderly in Japan. Archives of Gerontology and Geriatrics, 48(1), 10-13. https://doi.org/10.1016/j.archger.2007.09.003

Østbye, T., Malhotra, R., Malhotra, C., Arambepola, C., \& Chan, A. (2013). Does support from foreign domestic workers decrease the negative impact of informal caregiving? Results from Singapore survey on informal caregiving. Journals of Gerontology Series B: Psychological Sciences and Social Sciences, 68(4), 609-621. https://doi.org/10.1093/geronb/gbt042

Piper, N. (2008). Feminisation of migration and the social dimensions of development: The Asian case. Third World Quarterly, 29(7), 1287-1303. https://doi.org/10.1080/01436590802386427

Pylli, E. (2019). Development of the education process and nowadays scientific knowledge against the globalization process. Knowledge International Journal, 30(2), 307-310.

Salvador-Carulla, L. (2010). Knowledge-in-practice in the care professions: Multidisciplinary perspectives. International Journal of Integrated Care, 10, e054. Retrieved from https://www.ncbi.nlm.nih.gov/pmc/articles/PMC2948680/

Sangasubana, N. (2011). How to conduct ethnographic research. Qualitative Report, 16(2), 567-573.

Sollund, R.A., \& Leonard, L. (2012). Transnational migration, gender and rights (Vol. 10). Binglay, UK: Emerald Group Publishing.

Suleman, F. (2015). The employment relationship in an (almost) structureless labour market: The case of domestic work. Cambridge Journal of Economics, 39, 733-750. https://doi.org/10.1093/cje/beu018

Tan, J. (2019). Dementia care work in Singapore: Embodied relations and power dynamics. Medical Anthropology, 38(1), 71-84.

Tang, H.N., Chong, W.H., Goh, W., Chan, W.P., \& Choo, S. (2012). Evaluation of family-centred practices in the early intervention programmes for infants and young children in Singapore with measure of processes of care for service providers and measure of beliefs about participation in family-centred service. Child: Care, Health and Development, 38(1), 54-60. https://doi.org/10.1111/j.1365-2214.2011.01259.x

Tayah, M.J. (2016). Skills development and recognition for domestic workers across borders. Research Series, ILO Geneva. Retrieved from https:/www.ilo.org/wcmsp5/groups/public/---ed_protect/--protrav/---migrant/documents/briefingnote/wcms_533536.pdf 
Tronto J.C. (2002). The "nanny" question in feminism. Hypatia, 17(2), 34-51. https://doi.org/10.1111/j.1527-2001.2002.tb00764.x

Tronto, J.C. (2007). Human rights, democracy and care. The Good Society, 16(2), 38-40. http://www.jstor.org/stable/20711265

Tronto, J.C. (2013). Caring democracy: Markets, equality, and justice. New York, NY: NYU Press.

Ueno, K. (2008). Foreign domestic workers in Singapore. In B. Molony \& E. Ochiai (Eds.), Asia's new mothers: Crafting gender roles and childcare networks in East and Southeast Asian societies (pp. 140-156). Kent, UK: Global Oriental Publishing. https://doi.org/10.1163/ej.9781905246373.i232.66

UENO, K., \& Belanger, D. (2019). Facebook activism among foreign domestic workers in Singapore. 東 京女子大学社会学年報=Tokyo Women's Christian University Annals of Sociology, (7), 39-56.

Walsh, K., \& Shutes, I. (2013). Care relationships, quality of care and migrant workers caring for older people. Ageing \& Society, 33(3), 393-420.

Watson, J., \& Smith, M.C. (2001). Caring science and the science of unitary human beings: A transtheoretical discourse for nursing knowledge development. Journal of Advanced Nursing, 37(5), $452-461$.

Wessels, A. (2015). Home sweet home? Work, life and well-being of foreign domestic workers in Singapore. HOME Research Report. doi: 10.13140/2.1.4090.1922

World Health Organization. (2017). Women on the move: Migration, care work and health. Retrieved February 2020, from https://www.who.int/gender-equity-rights/knowledge/women-on-themove/en/

Yeates, N. (2011). Going global: The transnationalization of care. Development and Change, 42(4), 1109-1130. https://doi.org/10.1111/j.1467-7660.2011.01718.x

Yeates, N. (2012). Global care chains: a state-of-the-art review and future directions in care transnationalization research. Global Networks, 12(2), 135-154. https://doi.org/10.1111/j.1471-0374.2012.00344.x

Yeoh, B.S., Huang, S., \& Gonzalez. J., III. (1999). Migrant female domestic workers: Debating the economic, social and political impacts in Singapore. International Migration Review, 33(1), 114 136. https://doi.org/10.1177/019791839903300105

Yeoh, B.S.A., \& Huang, S. (2009). Foreign domestic workers and home- based care for elders in Singapore. Journal of Aging \& Social Policy, 22(1), 69-88. 